\title{
PENGETAHUAN GENERASI MILENIAL SUNDA PERKOTAAN TERHADAP PERALATAN DAPUR TRADISIONAL SUNDA
}

\author{
(The Urban Sundanese Millennial Generation's Knowledge \\ on Sundanese Traditional Kitchen Utensils)
}

\author{
Dindin Samsudin \\ Balai Bahasa Provinsi Jawa Barat \\ Jalan Sumbawa 11, Bandung, Jawa Barat 40113 \\ Pos-el: dins_samsoe75@yahoo.com
}

(Naskah Diterima 6 April 2021-Direvisi 18 Agustus 2021—Disetujui 23 September 2021)

\begin{abstract}
Many regional languages in Indonesia are threatened with extinction due to the decreasing number of the younger generations who use the language. There are only 13 regional languages that have more than one million speakers and most of the speakers are older generations. Sundanese language is one of that 13 languages. However, nowadays the Sundanese language is starting to be sidelined and abandoned by the younger generations, especially children. Based on the observations of Sundanese language observers currently, the number of children in Bandung who can speak Sundanese is less than fifty percent. This study aimed to reveal the urban Sundanese millennial generation's knowledge on the Sundanese vocabulary of traditional kitchen utensils. This study needs to be done since the vocabulary of household appliances is the closest in the home domain. This research uses a quantitative approach with a survey method. The data analysis technique for the research problem is descriptive statistics (crosstab). The results showed that the knowledge of the urban Sundanese millennial generation on the vocabulary of Sundanese traditional kitchen utensils reached an average of $87.17 \%$, which can be categorized as good. Although it is categorized as good, some respondents do not know the name of the kitchen utensils.
\end{abstract}

Keywords: millennial generation, Sundanese, kitchen utensils

\begin{abstract}
Abstrak
Banyak bahasa daerah di Indonesia terancam punah karena semakin berkurangnya generasi muda pemakai bahasa tersebut. Kini hanya terdapat tiga belas bahasa daerah yang memiliki jumlah penutur di atas satu juta orang, itu pun sebagian besar generasi tua. Bahasa Sunda termasuk di antara tiga belas bahasa tersebut. Walaupun demikian, saat ini bahasa Sunda mulai dikesampingkan dan ditinggalkan oleh generasi muda, khususnya anak-anak. Berdasarkan pengamatan para pemerhati bahasa Sunda, saat ini jumlah anak-anak di Kota Bandung yang dapat berbahasa Sunda tidak sampai lima puluh persen. Penelitian ini bertujuan untuk mengungkapkan penguasaan generasi milenial Sunda perkotaan terhadap kosakata peralatan rumah tangga di dapur tradisional Sunda. Hal ini perlu dilakukan karena kosakata peralatan rumah tangga merupakan kosakata terdekat yang ada di lingkungan rumah. Penelitian ini menggunakan pendekatan kuantitatif dengan metode survei. Analisis data menggunakan statistika deskriptif (crosstab). Hasil penelitian menunjukkan bahwa pengetahuan generasi milenial Sunda perkotaaan terhadap kosakata peralatan rumah tangga di dapur tradisional Sunda mencapai rata-rata $87,17 \%$ sehingga dapat dikategorikan baik. Walaupun secara umum pengetahuan generasi milenial Sunda terhadap peralatan dapur
\end{abstract}


dikategorikan baik, ada beberapa responden yang tidak mengetahui nama peralatan dapur tersebut.

Kata kunci: generasi milenial, Sunda, alat dapur

\section{PENDAHULUAN}

Sunda adalah salah satu suku bangsa terbesar di Indonesia yang mendiami wilayah Jawa Barat. Bahasa daerah yang dituturkan oleh masyarakat Sunda dalam berkomunikasi sehari-hari adalah bahasa Sunda. Sunda merupakan bahasa daerah kedua terbesar di Indonesia setelah bahasa Jawa. Menurut Lauder, jumlah penutur bahasa Jawa adalah 75.200.000 orang, sedangkan penutur bahasa Sunda sebanyak 27.000.000 orang (Lauder, 2012). Menurut SIL (SIL Internasional, 2001), terdapat beberapa bahasa daerah yang diperkirakan jumlah penuturnya cukup banyak, bahkan lebih dari satu juta, di antaranya bahasa Jawa (75.200.000 penutur) dan bahasa Sunda (27.000.000 penutur).

Selain di Jawa Barat, bahasa Sunda juga memiliki wilayah tutur di beberapa wilayah Indonesia lainnya, misalnya di Banten, DKI Jakarta, Jawa Tengah, Lampung, Bengkulu, dan Sulawesi Utara (badanbahasakemdikbud.go.id). Di Provinsi DKI Jakarta, bahasa Sunda dituturkan di Pulau Lancang Besar, Kelurahan Pulau Pari, Kecamatan Kepulauan Seribu Utara, Administrasi Kepulauan Seribu, dan di Jatinegara Kaum, Kecamatan Pulogadung, Kota Jakarta Timur.

Walaupun demikian, berdasarkan hasil penghitungan dialektometri, bahasa Sunda di Provinsi DKI Jakarta dengan bahasa Sunda di Jawa Barat memiliki persentase perbedaan $51,25 \%$ sehingga dikatakan beda dialek (badanbahasakemdikbud.go.id).

Pelestarian bahasa Sunda harus benarbenar dilakukan agar tidak lenyap ditelan bumi. Menurut catatan Lewis, dkk. (2013), di Indonesia terdapat 13 bahasa lokal yang sudah punah, 340 terancam punah, dan hanya 366 masih bertahan dan lestari.
Catatan lain menyebutkan bahwa dari 340 bahasa yang terancam punah tersebut, 75 bahasa akan segera punah dan sisanya menyusul ikut punah apabila tidak ada upaya pelindungan dan penyelamatan (Tjia, 2013).

Isu kematian bahasa Sunda sudah terdengar sejak satu abad yang lalu ketika pengarang Sunda, Raden Haji Moehamad Moesa, dalam tulisannya menyebutkan bahwa bahasa Sunda baru sembuh dari "sakit" dan belum "sehat" benar (Sobarna, 2007). Hal tersebut dikatakannya sehubungan dengan kondisi bahasa Sunda pada saat itu yang sudah banyak menyerap kosakata asing. Namun, dalam pengamatan sekilas dan secara umum saat ini bahasa Sunda tidak termasuk bahasa yang aman (safe), tetapi bahasa yang mengalami tahap kemunduran (eroding) atau termasuk kondisi stabil, tetapi terancam punah (stable but threatened) (Sobarna, 2007).

Ancaman kepunahan bahasa Sunda mungkin terjadi karena stigma di kalangan generasi muda yang menilai bahasa daerah kuno, rumit, pinggiran, dan kurang terdidik. Hal tersebut seperti dikatakan Sobarna bahwa kekurangmampuan generasi muda berbahasa daerah diperparah dengan adanya penilaian yang kurang baik terhadap bahasa daerah. Salah satunya penilaian yang menganggap bahwa bahasa daerah erat kaitannya dengan hal yang konservatif.

$$
\text { Perkembangan zaman yang }
$$
berimbas pada perubahan berbagai aspek kehidupan juga sangat memengaruhi ditinggalkannya bahasa Sunda oleh generasi muda. Sebagai akibat dari pengaruh budaya global, kini generasi muda Bandung cenderung menggunakan bahasa Indonesia ketika berkomunikasi dan tak jarang diselingi juga dengan bahasa asing. Sobarna mengatakan bahwa kekurangmampuan generasi muda dalam menggunakan bahasa daerah tidak terlepas dari pengaruh semakin 
kuatnya eksistensi bahasa nasional. Menurut Sobarna, bahasa Indonesia kini digunakan pula pada situasi tidak resmi, termasuk di lingkungan keluarga (Sobarna, 2007).

Salah satu faktor utama yang perlu digarisbawahi ialah tidak adanya pengajaran bahasa Sunda dari orang tua kepada anakanaknya. Hal tersebut sesuai dengan pernyataan Kurnia yang mengatakan bahwa generasi tua Sunda enggan mencoba terjun langsung ke "kantong-kantong" pewarisan budaya, dalam hal ini generasi muda. Menurut Kurnia, untuk memperkuat pemahaman generasi muda kepada budaya Sunda, penting sekali mengintensifkan pengajaran bahasa Sunda kepada mereka (Kurnia, 2008).

Hal tersebut berpangkal pada peran orang tua. Orang tua atau generasi tua Sunda harus rela mengesampingkan ego mereka dan tetap memperkenalkan dan menjaga budaya Sunda, misalnya selalu menggunakan bahasa Sunda kepada anakanaknya di rumah agar tidak terjadi adanya kesenjangan antargenerasi dalam rangka pewarisan bahasa daerah (Kurnia, 2008).

Jika kenyataan tersebut terus terjadi, tidak menutup kemungkinan beberapa generasi ke depan bahasa Sunda akan punah. Hal tersebut sesuai dengan tahap-tahap kematian bahasa yang diajukan oleh Crystal dan Lauder: (1) berpotensi terancam punah (potentially endangered languages), yaitu bahasa-bahasa yang secara sosial dan ekonomi tergolong minoritas serta mendapat tekanan yang cukup besar dari mayoritas, generasi mudanya (anak-anak) sudah mulai berpindah ke bahasa mayoritas dan jarang menggunakan bahasa ibu; (2) terancam punah (endagered languages), yaitu bahasabahasa yang tidak mempunyai lagi generasi muda yang dapat berbahasa ibu, penutur yang fasih hanyalah kelompok generasi menengah (dewasa); (3) sangat terancam punah (seriously endangered languages), yaitu bahasa yang hanya berpenutur generasi tua berusia di atas 50 tahun; (4) sekarat (moribund languages), yaitu bahasa yang dituturkan oleh beberapa orang tua sekitar
70 tahun ke atas; (5) punah (extinct languages), yaitu bahasa yang penuturnya tinggal satu orang sehingga tidak ada teman berkomunikasi dalam bahasa itu. Tahap ini merupakan tahap yang sangat kritis (Crystal, 1990; Multamia, 2004).

Penguasaan leksikal Sunda generasi milenial Sunda di wilayah perkotaan menjadi pusat penelitian ini. Penelitian ini akan difokuskan kepada generasi alfa. Menurut Bencsik, Csikos, dan Juhez generasi alfa adalah generasi milenial yang lahir setelah tahun 2010. Usia responden dalam penelitian ini dibatasi 14-25 tahun (Bencsik, A., Csikos, G., \& Juhaz, 2016).

Kosakata alat dapur harus diketahui oleh generasi muda karena berada di dalam lingkungan rumah. Ketika berkomunikasi tentu harus ada hubungan timbal balik dan saling pengertian antara pembicara dan mitra bicara. Semua kosakata yang dipilih dan digunakan harus dapat dimengerti, baik secara semantik maupun kontekstual. Ketidaktahuan makna kosakata yang dituturkan akan membuat komunikasi tidak lancar.

Berdasarkan latar belakang tersebut, fokus masalah penelitian ini ialah pengetahuan generasi milenial Sunda perkotaaan terhadap kosakata peralatan rumah tangga di dapur tradisional Sunda. Penelitian ini bertujuan untuk mengungkapkan penguasaan generasi milenial Sunda perkotaan terhadap kosakata peralatan rumah tangga di dapur tradisional Sunda.

Penelitian yang relevan pernah dilakukan oleh peneliti terdahulu. Akan tetapi, penelitian tersebut berbeda dari segi usia dan objek bahasa. Markus, dkk. melakukan penelitian berjudul "Penguasaan Kosakata Bahasa Indonesia Anak Usia 4-5 Tahun" di TK Kasih Ibu Desa Kuala Lapang, Kecamatan Malinau, Kabupaten Malinau Barat. Berdasarkan hasil penelitiannya, anak usia 4-5 tahun sudah menguasai hampir semua kelas kata bahasa Indonesia, mulai dari nomina, verba, adjektiva, adverbia, pronomina, numeralia, 
preposisi, konjungsi, sampai interjeksi (Markus, 2017).

Penelitian penguasaan kosakata setakat ini pada umumnya difokuskan pada penguasaan kosakata bahasa Indonesia. Penguasaan kosakata secara khusus terhadap bahasa Sunda belum sepenuhnya terdeskripsikan. Penelitian penguasaan leksikal bahasa Sunda untuk kelompok masyarakat dipandang penting karena hasilnya dapat merefleksikan penguasaan masyarakat Sunda terhadap kosakata bahasa Sunda sebagai bahasa ibu. Karena luasnya wilayah Jawa Barat, penelitian penguasaan leksikal masyarakat Sunda terhadap peralatan di dapur tradisional Sunda ini akan difokuskan kepada generasi milenial Sunda di wilayah perkotaan.

Hasil penelitian ini dapat dimanfaatkan secara praktis, yaitu untuk pengambilan kebijakan politik bahasa nasional. Hasil penelitian ini juga dapat dimanfaatkan sebagai bahan rekomendasi kebijakan bahasa dalam upaya melestarikan bahasa daerah sebagai khazanah budaya bangsa. Dengan keadaan kebahasaan yang demikian kompleks, perlu dibuat garis besar kebijakan bahasa berdasarkan hasil observasi dan penelitian yang mendalam tentang kondisi dan sikap kebahasaan di Provinsi Jawa Barat.

Teori sosiolinguistik berkaitan dengan teori sikap bahasa karena sosiolinguistik memandang bahasa sebagai suatu institusi sosial, baik individu maupun kelompok masyarakat yang melakukan interaksi sosial. Menurut Hudson, sosiolinguistik mencakupi bidang kajian yang sangat luas, tidak hanya menyangkut wujud formal bahasa dan variasinya, tetapi juga penggunaan bahasa di masyarakat (Hudson, 1996). Penggunaan bahasa tersebut mencakupi faktor kebahasaan dan faktor nonkebahasaan.

Penelitian ini bertolak dari pengetahuan kebahasaan dan sikap bahasa generasi milenial Sunda. Data penelitian berupa jawaban responden atas pertanyaan dan pernyataan yang diajukan melalui angket/kuesioner. Dengan kata lain, objek penelitian ini adalah jawaban dan tanggapan yang berisikan pengetahuan dan sikap responden (generasi milenial Sunda) terhadap bahasa Sunda.

Halim yang mengutip pendapat Garvin dan Mathiot mengatakan bahwa sikap bahasa setidak-tidaknya mengandung tiga ciri pokok, yaitu

(1) sikap kesetiaan yang mendorong suatu masyarakat bahasa mempertahankan bahasanya dan jika perlu mencegah adanya pengaruh asing,

(2) sikap kebanggaan bahasa yang mendorong orang mengembangkan bahasanya dan menggunakannya sebagai lambang identitas dan kesatuan masyarakat,

(3) sikap kesadaran akan adanya norma bahasa yang mendorong orang menggunakan bahasanya dengan cermat dan santun merupakan faktor yang sangat besar pengaruhnya terhadap perbuatan, yaitu kegiatan penggunaan bahasa (Halim, 1983).

Ketiga ciri yang dikemukakan tersebut merupakan ciri-ciri sikap positif terhadap bahasa. Apabila ketiga ciri bahasa tersebut melemah atau sudah menghilang dari diri seseorang atau suatu komunitas, berarti telah terjadi sikap negatif terhadap bahasa tersebut.

Sementara itu, terdapat beberapa faktor yang memengaruhi pemertahanan bahasa menurut Sumarsono, yaitu faktor kemultibahasaan, industrialisasi, urbanisasi, jumlah penutur, konsentrasi permukiman, dan kepentingan politik, serta faktor ekonomi, faktor agama, dan faktor politik (Sumarsono dan Partana, 2004:200). Faktorfaktor lain dalam pemertahanan bahasa yang ditemukan Sumarsono dalam penelitiannya mengenai bahasa Melayu Loloan di Bali adalah faktor konsentrasi permukiman, adanya toleransi dari masyarakat pengguna bahasa lain selain bahasa Melayu Loloan, minimnya interaksi dengan budaya lain, loyalitas yang tinggi terhadap bahasa, dan 
regenerasi penutur bahasa (Sumarsono, 1993).

Berdasarkan teori tadi terlihat bahwa faktor pemertahanan bahasa adalah pengajaran dan regenerasi penutur bahasa. Penelitian ini akan dikhususkan untuk melihat regenerasi penutur bahasa Sunda di wilayah perkotaan di Jawa Barat melalui pengajaran leksikal bahasa Sunda.

Jumlah penduduk yang terus meningkat menjadikan kota-kota yang saling berdekatan secara geografis akan terintegrasi membentuk suatu kawasan metropolitan, seperti kawasan metropolitan Bandung Raya. Bandung Raya meliputi wilayah Kota Bandung, Kota Cimahi, Kabupaten Bandung, Kabupaten Bandung Barat, dan sebagian wilayah Kabupaten Sumedang.

Kawasan Bandung Raya telah membentuk satu kesatuan kawasan urban. Persamaan dan perbedaan ruang-ruang sosial yang diciptakan berdasarkan aspek kehidupan masyarakat membentuk suatu kota yang beraneka ragam. Dengan demikian, kota merupakan hasil dari kumpulan ruang-ruang sosial yang dibentuk oleh pola kehidupan masyarakat yang beraneka ragam.

Masyarakat urban pada dasarnya adalah masyarakat pendatang dari berbagai daerah yang kemudian bertemu dan berinteraksi dalam suatu wilayah. Untuk kepentingan berinteraksi, masyarakat urban sudah tentu memanfaatkan bahasa persatuan, bahasa Indonesia. Hal tersebut tentu dapat memengaruhi penggunaan dan keberadaan bahasa daerah.

Pengaruh globalisasi dan perkembangan iptek membawa dampak terhadap perkembangan bahasa generasi muda. Media sosial adalah salah satu media yang memiliki peran penting dalam perkembangan bahasa. Bahkan, bahasa generasi muda menggeser penggunaan bahasa Indonesia. Para remaja lebih tertarik menggunakan bahasa tersebut karena dapat digunakan sesuka keinginan mereka. Perkembangan media sosial yang sangat pesat, seperti Facebook, Instagram, Youtube, dan Twitter memengaruhi bahasa generasi muda, terutama generasi milenial.

Istilah "milenial" pertama kali dicetuskan Howe dan Strauss dalam bukunya yang berjudul Millennials Rising: The Next Great Generation (Febriani, 2020). Milenial merupakan sebutan untuk kelompok demografis atau generasi Y (gen Y) yang lahir setelah generasi X. Sebutan milenial (millenials) untuk generasi $\mathrm{Y}$ ini mulai dipakai pada editorial koran besar Amerika Serikat pada Agustus 1993 karena diperkirakan individu pada generasi ini akan mencapai dewasa sekitar pergantian abad ke-21 atau pergantian era milenium (masa atau jangka waktu seribu tahun).

Ada beberapa pendapat yang mendefinisikan kelompok milenial atau milenium ini. Hal ini terjadi karena untuk menentukan sebuah generasi dipengaruhi oleh banyak faktor, seperti geografis dan budaya. Selain itu, orang-orang dalam populasi tersebut digambarkan yang mengalami peristiwa penting yang sama dalam jangka waktu tertentu. Dengan demikian, tidak ada patokan waktu yang tepat dan sama.

Kemajuan zaman juga menyebabkan komposisi penduduk setiap generasi berubah,. Komposisi kelompok baby boomers mulai menurun. Jjika terkait dengan usia produktif dan komposisi angkatan kerja, jumlah kelompok generasi $\mathrm{X}$ dan $\mathrm{Y}$ yang terbanyak. Selain itu, mulai bangkit generasi yang memasuki angkatan kerja yang disebut dengan generasi $\mathrm{Z}$.

Penelitian Bencsik, Csikos, dan Juhez menunjukkan masuknya generasi $\mathrm{Z}$ di dalam kelompok generasi seperti tampak dalam tabel 1 berikut.

Tabel 1

Perbedaan Generasi

\begin{tabular}{|c|c|}
\hline $\begin{array}{c}\text { Tahun } \\
\text { Kelahiran }\end{array}$ & \multicolumn{1}{|c|}{ Nama Generasi } \\
\hline $1925-1946$ & Veteran generation \\
\hline $1946-1960$ & Baby boom generation \\
\hline $1960-1980$ & X generation \\
\cline { 2 - 3 } &
\end{tabular}




\begin{tabular}{|c|l|}
\cline { 2 - 2 } $1980-1995$ & $Y$ generation \\
\hline $1995-2010$ & $Z$ Zeneration \\
\hline $2010+$ & Alfa generation \\
\hline
\end{tabular}

Enam kelompok generasi tersebut memiliki karakteristik yang berbeda-beda. Generasi paling muda yang baru memasuki angkatan kerja adalah generasi $\mathrm{Z}$, disebut juga $i$-Generation atau generasi internet. Generasi $\mathrm{Z}$ memiliki kesamaan dengan generasi Y. Akan tetapi, generasi $\mathrm{Z}$ mampu mengaplikasikan semua kegiatan dalam satu waktu (multi tasking), seperti menggunakan media sosial, menggunakan ponsel, browsing menggunakan PC, dan mendengarkan musik menggunakan headset. Segala hal yang dilakukan kebanyakan berhubungan dengan dunia maya. Sejak kecil generasi ini sudah mengenal teknologi dan akrab dengan gawai canggih yang secara tidak langsung berpengaruh terhadap kepribadian.

Masyarakat Sunda memiliki banyak nama alat dapur rumah tangga tradisional khas yang sebagian besar terbuat dari bambu. Namun, ada juga alat dapur yang terbuat dari aluminium dan kuningan. Alat dapur tradisional Sunda mungkin sudah mulai ditinggalkan dan dianggap kuno oleh sebagai besar masyarakat suku Sunda itu sendiri. Hal itu terjadi karena seiring perkembangan zaman mereka sudah beralih menggunakan alat dapur modern. Generasi alfa belum tentu tahu nama-nama alat dapur rumah tangga tradisional Sunda, seperti hawu, boboko, aseupan, seeng, tolombong, hihid, kastrol, hawu, ayakan, coet, serta dulang dan halu.

\section{METODE PENELITIAN}

Pendekatan yang digunakan dalam penelitian ini berkaitan dengan pendekatan teoretis dan metodologis. Pendekatan teoretis mengacu kepada pendekatan sosiolinguistik karena sosiolinguistik termasuk teori atau ilmu yang berkaitan dengan pemakaian bahasa dalam kaitan dengan masyarakat (Chaer, 2010).
Sementara itu, pendekatan metodologis menggunakan pendekatan kuantitatif yang bersifat deskriptif, yaitu penafsiran data yang berkenaan dengan fakta, variabel, dan fenomena yang terjadi saat penelitian berlangsung dengan menyajikannya secara apa adanya.

Penelitian ini menggunakan metode survei, yaitu penelitian yang mengambil sampel dari populasi dan mengumpulkan data melalui kuesioner sebagai alat pengumpul data yang pokok. Penerapan metode itu bertujuan menggambarkan dan menafsirkan hal yang berkenaan dengan suatu kondisi atau gejala seperti apa adanya atau mendeskripsikan gejala faktual dan kaitan berbagai variabel masalah yang diteliti secara sistematis.

Populasi penelitian ini adalah generasi alfa yang ada di wilayah Bandung Raya, baik laki-laki maupun perempuan. Dalam penelitian bahasa sampel yang besar tidak diperlukan karena perilaku linguistik cenderung lebih homogen dibandingkan perilaku-perilaku lainnya (Mahsun, 2005). Ahsen (dalam Mahsun, 2005) menyebutkan bahwa penelitian sosiolinguistik yang hasilnya telah diterbitkan ternyata menggunakan sampel dalam jumlah yang tidak besar. Sampel yang digunakan dalam penelitian ini berjumlah 86 orang dari populasi yang mewakili generasi alfa di wilayah perkotaan.

Data yang digunakan adalah data yang diperoleh melalui penyebaran angket yang berpedoman pada Skala Likert. Kosakata yang dijadikan sebagai pertanyaan dalam angket adalah kosakata peralatan dapur yang pada umumnya berada di dapur tradisional Sunda. Data yang diperoleh adalah data kuantitatif, yaitu data berupa angka-angka dari hasil pengukuran yang berupa pertanyaan yang terkait dengan alat tradisional yang ada di dapur Sunda.

Pengumpulan data penelitian ini dilakukan secara purposive sampling. Karakteristik sampel adalah generasi alfa yang berusia antara 13-25 tahun, bersuku Sunda, dan berprofesi sebagai pelajar atau 
mahasiswa. Populasi sampel berada di wilayah Bandung Raya. Pemilihan lokasi ini dilakukan karena masyarakat Sunda yang ada di wilayah tersebut mewakili bagian wilayah perkotaan di Jawa Barat.

Setelah terkumpul, data diolah dengan langkah-langkah (1) membuat tabulasi skor angket pengetahuan generasi milenial Sunda dan (2) membuat skor keseluruhan hasil tes.

Data kuantitatif penguasaan leksikal peralatan dan istilah dapur masyarakat Sunda dianalisis dengan menggunakan model analisis yang terdiri atas tiga kegiatan utama yang berkaitan satu sama lain. Kegiatan tersebut meliputi reduksi data, penyajian data, dan penarikan simpulan/verifikasi.

Data kuantitatif yang diperoleh melalui teknik kuesioner dianalisis secara deskriptif kuantitatif berdasarkan penghitungan frekuensi dan persentase. Penghitungan diawali dengan menghitung frekuensi dan persentase karakteristik responden. Penghitungan lanjutan adalah menghitung frekuensi dan persentase setiap item pernyataan yang merupakan bagian indikator penghitungan penguasaan leksikal peralatan tradisional dapur masyarakat Sunda.

Peneliti berhipotesis bahwa generasi milenial Sunda di perkotaaan tidak mengetahui nama kosakata peralatan rumah tangga di dapur tradisional Sunda. Hipotesis dibuktikan dengan statistika inferensial dengan uji normalitas. Data yang diuji ialah pengetahuan kosakata peralatan rumah tangga di dapur tradisional Sunda yang dimiliki generasi milenial Sunda perkotaaan. Hipotesis uji normalitas ialah sebagai berikut.

H0: Data pengetahuan tentang kosakata peralatan rumah tangga di dapur tradisional Sunda yang dimiliki generasi milenial Sunda perkotaaan berdistribusi normal.

H1: Data pengetahuan tentang kosakata peralatan rumah tangga di dapur tradisional Sunda yang dimiliki generasi milenial Sunda perkotaaan berdistribusi tidak normal.

Statistik uji: Uji Shapiro-Wilk pada taraf signifikansi $\alpha=0,05$ dengan kriteria uji terima $\mathrm{H} 0$ jika nilai Sig. $\geq \alpha=0,05$ atau tolak H0 jika nilai Sig. $<\alpha=0,05$.

\section{PEMBAHASAN}

\section{Karakteristik Subjek Penelitian}

Karakteristik subjek penelitian ini ditinjau dari dua aspek, yaitu 1) jenis kelamin, dan 2) tingkat pendidikan. Karakteristik usia tidak diungkapkan secara khusus karena berdasarkan tingkat pendidikan akan diketahui usia subjek penelitian. Hal tersebut terlihat dalam tabel 2 berikut.

Tabel 2

Karakteristik Subjek Penelitian

\begin{tabular}{|c|c|c|c|c|c|c|}
\hline \multicolumn{7}{|c|}{ Case Processing Summary } \\
\hline & \multicolumn{6}{|c|}{ Cases } \\
\hline & \multicolumn{2}{|c|}{ Valid } & \multicolumn{2}{|c|}{ Missing } & \multicolumn{2}{|c|}{ Total } \\
\hline & $\mathrm{N}$ & Percent & $\mathrm{N}$ & Percent & $\mathrm{N}$ & Percent \\
\hline Wilayah * Jenis Kelamin & 86 & $100.0 \%$ & 0 & $0.0 \%$ & 86 & $100.0 \%$ \\
\hline Wilayah * Tingkat Pendidikan & 86 & $100.0 \%$ & 0 & $0.0 \%$ & 86 & $100.0 \%$ \\
\hline
\end{tabular}

Pengolahan data penelitian dilakukan dengan bantuan software SPSS. Selanjutnya, hasil pengolahan data gambaran umum

karakteristik subjek penelitian mengacu pada tabel 3 di bawah ini. 
Tabel 3

Pedoman Penginterpretasian Persentase Jawaban

\begin{tabular}{|c|c|}
\hline $\begin{array}{c}\text { Persentase } \\
\text { Jawaban }(\mathbf{P})\end{array}$ & Penafsiran \\
\hline $\mathrm{P}=0,00$ & Tidak ada \\
\hline $0,00<\mathrm{P} \leq 5,00$ & Hampir tidak ada \\
\hline $5,00<\mathrm{P} \leq 25,00$ & Sebagian kecil \\
\hline $25,00<\mathrm{P}<50,00$ & Hampir setengahnya \\
\hline $\mathrm{P}=50,00 \%$ & Setengahnya \\
\hline $50,00<\mathrm{P} \leq 75,00$ & Lebih dari setengahnya \\
\hline $75,00<\mathrm{P} \leq 95,00$ & Sebagian besar \\
\hline $95,00<\mathrm{P}<100,00$ & Hampir seluruhnya \\
\hline $\mathrm{P}=100 \%$ & Seluruhnya \\
\hline
\end{tabular}

\section{Karakteristik Subjek Penelitian Berdasarkan Jenis Kelamin}

Untuk memperoleh data terperinci mengenai jumlah keseluruhan responden dan jumlah responden berdasarkan jenis kelamin, data diolah dengan menggunakan SPSS Versi 22 dengan cara tabulasi silang antara lokasi penelitian dan jenis kelamin. Hasil pengolahan data ditampilkan pada tabel 4 berikut.

Tabel 4

Keadaan Subjek Penelitian Ditinjau Berdasarkan Jenis Kelamin

\begin{tabular}{|c|c|c|c|}
\hline \multicolumn{3}{|c|}{ Wilayah * Jenis Kelamin Crosstabulation } \\
\hline & \multicolumn{2}{|c|}{ Jenis Kelamin } & \multirow{2}{*}{ Total } \\
\cline { 2 - 3 } & Laki-laki & Perempuan & \\
\hline Count & 44 & 42 & 86 \\
\hline $\begin{array}{l}\text { \% within } \\
\text { Wilayah }\end{array}$ & $51.2 \%$ & $48.8 \%$ & $100.0 \%$ \\
\hline
\end{tabular}

Berdasarkan tabel 4 terlihat bahwa jumlah seluruh responden adalah 86 orang yang terdiri atas 44 orang laki-laki $(51,2 \%)$ dan 42 orang perempuan (48,8\%). Dengan demikian, responden penelitian ini lebih dari setengahnya berjenis kelamin laki-laki.

\section{Karakteristik Subjek Penelitian Berdasarkan Tingkat Pendidikan}

Hasil pengolahan data karakteristik subjek penelitian berdasarkan tingkat pendidikan ditampilkan pada tabel 5 .

Tabel 5

Keadaan subjek penelitian Ditinjau Berdasarkan Tingkat Pendidikan

\begin{tabular}{|c|c|c|c|c|c|}
\hline \multicolumn{5}{|c|}{ Wilayah * Tingkat Pendidikan Crosstabulation } \\
\hline & \multicolumn{4}{|c|}{ Tingkat Pendidikan } & \multirow{2}{*}{ Total } \\
\cline { 2 - 5 } & SLTP & SLTA & PT & $\begin{array}{c}\text { Tidak } \\
\text { diisi }\end{array}$ & \\
\hline Count & 56 & 10 & 17 & 3 & 86 \\
\hline $\begin{array}{c}\text { \% within } \\
\text { Wilayah }\end{array}$ & $65.1 \%$ & $11.6 \%$ & $19.8 \%$ & $3.5 \%$ & $100.0 \%$ \\
\hline
\end{tabular}

Dari tabel 5 terlihat bahwa responden yang berpendidikan SLTP (usia 14-16 tahun) berjumlah 56 orang $(65,1 \%)$, berpendidikan SLTA (usia 17-20 tahun) berjumlah 10 orang $(11,6 \%)$, berpendidikan S-1 (21-25 tahun) berjumlah 17 orang $(19,8 \%)$, dan 3 orang responden $(3,5 \%)$ tidak diketahui latar belakang pendidikan dan usianya. Berdasarkan tabel 5 terlihat bahwa responden penelitian ini lebih dari setengahnya berlatar belakang pendidikan SLTP (usia 14-16 tahun).

\section{Hasil Pengolahan Data Pengetahuan Generasi Milenial Sunda Perkotaan terhadap Peralatan di Dapur Tradisional Sunda}

Beberapa alat rumah tangga di dapur tradisional Sunda, seperti hihid, jojodog, gentong aseupan, songsong, seeng, nyiru, tolombong, tetenong, dulang-halu, dan 
hawu mungkin sudah mulai ditinggalkan dan dianggap kuno oleh sebagai besar masyarakat suku Sunda itu sendiri. Hal tersebut terjadi karena mereka sudah beralih menggunakan alat dapur modern.

Suranny mengungkapkan bahwa sejalan dengan perkembangan ilmu pengetahuan dan teknologi saat ini, peran peralatan dapur tradisional ada yang mengalami perubahan dari alat bantu untuk memasak menjadi aksesoris hiasan atau suvenir tamu (Suranny, 2015).

Hasil pengolahan data pengetahuan generasi milenial Sunda perkotaan terhadap peralatan di dapur tradisional Sunda dapat dilihat dalam uraian berikut.

\section{Pengetahuan Generasi Milenial Sunda Perkotaan terhadap Peralatan di Dapur Tradisional Sunda}

\section{Aseupan}

Aseupan adalah perabot dapur di masyarakat Sunda. Aseupan berbentuk kerucut, terbuat dari anyaman bambu, dan digunakan untuk memasak nasi dengan cara dikukus (Sucipto, dkk., 2000). Dalam bahasa Indonesia, perabot dapur ini disebut dengan kukusan. Pengetahuan generasi milenial Sunda perkotaan terhadap aseupan dapat dilihat dalam tabel 6 berikut.

Tabel 6

Pengetahuan Subjek Penelitian terhadap Aseupan

\begin{tabular}{|c|c|c|c|}
\hline \multicolumn{3}{|c|}{ Wilayah * Aseupan Crosstabulation } \\
\hline & \multicolumn{2}{|c|}{ Aseupan } & \multirow{2}{*}{ Total } \\
\cline { 2 - 3 } & Tidak tahu & Tahu & \\
\hline $\begin{array}{c}\text { Count } \\
\% \text { within } \\
\text { Wilayah }\end{array}$ & 14 & 72 & 86 \\
\cline { 2 - 3 } & $16.3 \%$ & $83.7 \%$ & $100.0 \%$ \\
\hline
\end{tabular}

Berdasarkan tabel 6 terlihat bahwa sebanyak 14 orang $(16.3 \%)$ responden generasi milenial di wilayah perkotaan tidak mengenal alat dapur aseupan dan 72 orang $(83,7 \%)$ mengetahuinya. Berdasarkan uraian tadi dapat disimpulkan bahwa sebagian besar generasi milenial Sunda di perkotaan tahu alat dapur aseupan.
Nyiru

Nyiru adalah adalah alat rumah tangga di dapur masyarakat Sunda. Nyiru berbentuk bundar, dibuat dari bambu yang dianyam, biasanya digunakan untuk menampi beras dan sebagainya (KBBI). Pengetahuan generasi milenial Sunda perkotaan terhadap nyiru dapat dilihat dalam tabel 7 berikut.

Tabel 7

Pengetahuan Subjek Penelitian terhadap Nyiru

\begin{tabular}{|c|c|c|c|}
\hline \multicolumn{3}{|c|}{ Wilayah * Aseupan Crosstabulation } \\
\hline \multirow{2}{*}{} & \multicolumn{2}{|c|}{ Nyiru } & \multirow{2}{*}{ Total } \\
\cline { 2 - 3 } & Tidak tahu & Tahu & \\
\hline $\begin{array}{c}\text { Count } \\
\% \text { within } \\
\text { Wilayah }\end{array}$ & 15 & 71 & 86 \\
\cline { 2 - 3 } & $17.4 \%$ & $82.6 \%$ & $100.0 \%$ \\
\hline
\end{tabular}

Berdasarkan tabel 7 terlihat bahwa sebanyak 15 orang $(17,4 \%)$ responden generasi milenial di wilayah perkotaan tidak tahu alat dapur nyiru dan 71 orang $(82,6 \%)$ mengetahui nyiru. Berdasarkan uraian tadi dapat disimpulkan bahwa sebagian besar generasi milenial Sunda di perkotaan tahu alat dapur nyiru.

\section{Tolombung/Jangki}

Tolombong/jangki adalah wadah berbentuk bundar cekung dengan alas agak persegi dan bahannya terbuat dari bambu yang dianyam rapat. Tolombong dapat disebut wadah serbaguna karena dapat digunakan untuk tempat nasi atau menyimpan barang pecah belah. Selain itu, tolombong juga dapat digunakan untuk menyimpan bahan makanan atau wadah gabah yang diangkut dari sawah ke rumah (Sucipto, dkk., 2000). Pengetahuan generasi milenial Sunda perkotaan terhadap tolombong/jangki dapat dilihat dalam tabel 8 berikut.

\section{Tabel 8}

Pengetahuan Subjek Penelitian terhadap Tolombong/Jangki

\begin{tabular}{|c|c|c|c|}
\hline \multicolumn{3}{|c|}{$\begin{array}{c}\text { Wilayah * Tolombong/Jangki } \\
\text { Crosstabulation }\end{array}$} \\
\hline & Tolombong/Jangki & \multirow{2}{*}{ Total } \\
\cline { 2 - 3 } & Tidak tahu & Tahu & \\
\hline Count & 19 & 67 & 86 \\
\hline
\end{tabular}




\begin{tabular}{|l|c|c|c|}
\hline $\begin{array}{l}\text { \% within } \\
\text { Wilayah }\end{array}$ & $22.1 \%$ & $77.9 \%$ & $100.0 \%$ \\
\hline
\end{tabular}

Berdasarkan tabel 8 terlihat bahwa sebanyak 19 orang $(22,1 \%)$ responden generasi milenial di wilayah perkotaan tidak tahu alat dapur tolombong/jangki dan 67 orang (77,9\%) mengetahui tolombong/jangki. Berdasarkan uraian tadi dapat disimpulkan bahwa sebagian besar generasi milenial Sunda perkotaan tahu alat dapur tolombong/jangki.

\section{Cukil}

Cukil adalah alat dapur terbuat dari kayu yang bentuk dan ukurannya lebih besar dari sendok. Cukil berfungsi untuk menyendok nasi. Dalam bahasa Indonesia alat ini disebut dengan centong nasi. Pengetahuan generasi milenial Sunda perkotaan terhadap cukil dapat dilihat dalam tabel 9 berikut.

Tabel 9

Pengetahuan Subjek Penelitian terhadap Cukil

\begin{tabular}{|c|c|c|c|}
\hline \multicolumn{3}{|c|}{ Wilayah * Cukil Crosstabulation } \\
\hline & \multicolumn{2}{|c|}{ Cukil } & \multirow{2}{*}{ Total } \\
\cline { 2 - 3 } & Tidak tahu & Tahu & \\
\hline $\begin{array}{c}\text { Count } \\
\% \text { within } \\
\text { Wilayah }\end{array}$ & 6 & 80 & 86 \\
\cline { 2 - 3 } & $7.0 \%$ & $93.0 \%$ & $100.0 \%$ \\
\hline
\end{tabular}

Berdasarkan tabel 9 terlihat bahwa hanya 6 orang $(7,0 \%)$ responden generasi milenial di wilayah perkotaan tidak tahu alat dapur cukil, sedangkan 80 orang $(93,0 \%)$ mengetahui cukil. Berdasarkan uraian tadi dapat disimpulkan bahwa sebagian besar generasi milenial Sunda di perkotaan tahu alat dapur cukil.

\section{Talenan}

Talenan adalah alat dapur terbuat dari papan keratan kayu dan sebagainya yang berfungsi sebagai landasan untuk memotong, mencincang, dan sebagainya (KBBI). Pengetahuan generasi milenial Sunda perkotaan terhadap talenan dapat dilihat dalam tabel 10 berikut.
Tabel 10

Pengetahuan Subjek Penelitian terhadap Talenan

\begin{tabular}{|c|c|c|c|}
\hline \multicolumn{3}{|c|}{ Wilayah * Talenan Crosstabulation } \\
\hline & \multicolumn{2}{|c|}{ Talenan } & \multirow{2}{*}{ Total } \\
\cline { 2 - 3 } & Tidak tahu & Tahu & \\
\hline $\begin{array}{c}\text { Count } \\
\text { \% within } \\
\text { Wilayah }\end{array}$ & 1 & 85 & 86 \\
\cline { 2 - 3 } & $1.2 \%$ & $98.8 \%$ & $100.0 \%$ \\
\hline
\end{tabular}

Berdasarkan tabel 10 terlihat bahwa hanya 1 orang $(1,2 \%)$ responden generasi milenial di wilayah perkotaan tidak tahu alat dapur talenan dan 85 orang $(98,8 \%)$ mengetahui talenan. Berdasarkan uraian tadi dapat disimpulkan bahwa hampir seluruh generasi milenial Sunda di perkotaan tahu alat dapur talenan.

\section{Hihid}

Hihid adalah alat untuk mengipasi nasi panas pada waktu mengaduk-aduk agar pulen dan dingin. Hihid bentuknya persegi empat, terbuat dari bambu yang dianyam, dan salah satu sisi panjangnya diberi bingkai bilah bambu sebagai pegangan. Selain dipakai untuk mengipasi nasi yang sedang diakeul, hihid juga dipakai untuk mengipasi bara api waktu membakar makanan, seperti sate dan jagung (Sucipto, dkk., 2000). Pengetahuan generasi milenial Sunda perkotaan terhadap hihid dapat dilihat dalam tabel 11 berikut.

Tabel 11

Pengetahuan Subjek Penelitian terhadap Hihid

\begin{tabular}{|c|c|c|c|}
\hline \multicolumn{3}{|c|}{ Wilayah * Hihid Crosstabulation } \\
\hline & \multicolumn{2}{|c|}{ Hihid } & \multirow{2}{*}{ Total } \\
\cline { 2 - 3 } & Tidak tahu & Tahu & \\
\hline $\begin{array}{c}\text { Count } \\
\% \text { within } \\
\text { Wilayah }\end{array}$ & 0 & 86 & 86 \\
\cline { 2 - 3 } & $0.0 \%$ & $100.0 \%$ & $100.0 \%$ \\
\hline
\end{tabular}

Berdasarkan tabel 11 terlihat bahwa tidak ada seorang pun $(0.0 \%)$ responden generasi milenial di wilayah perkotaan yang tidak tahu alat dapur hihid. Dapat disimpulkan bahwa generasi milenial Sunda di perkotaan seluruhnya tahu alat dapur hihid. 
Siwur

Siwur adalah alat penciduk air yang dibuat dari tempurung kelapa dan sebagainya yang diberi tangkai (KBBI). Dalam bahasa Indonesia, siwur disebut dengan sibur. Pengetahuan generasi milenial Sunda perkotaan terhadap siwur dapat dilihat dalam tabel 12 berikut.

Tabel 12

Pengetahuan Subjek Penelitian terhadap Siwur

\begin{tabular}{|c|c|c|c|}
\hline \multicolumn{3}{|c|}{ Wilayah * Siwur Crosstabulation } \\
\hline & \multicolumn{2}{|c|}{ Siwur } & \multirow{2}{*}{ Total } \\
\cline { 2 - 3 } & $\begin{array}{c}\text { Tidak } \\
\text { tahu }\end{array}$ & Tahu & \\
\hline $\begin{array}{c}\text { Count } \\
\% \text { within } \\
\text { Wilayah }\end{array}$ & 15 & 71 & 86 \\
\cline { 2 - 3 } & $17.4 \%$ & $82.6 \%$ & $100.0 \%$ \\
\hline
\end{tabular}

Berdasarkan tabel 12 terlihat bahwa 15 orang $(17,4 \%)$ responden generasi milenial di wilayah perkotaan tidak tahu alat dapur siwur dan 71 orang $(82,6 \%)$ responden di wilayah perkotaan mengetahui siwur. Berdasarkan uraian tadi dapat disimpulkan bahwa sebagian besar generasi milenial Sunda di perkotaan tahu alat dapur siwur.

\section{Boboko}

Boboko adalah tempat nasi terbuat dari anyaman bambu atau rotan (KBBI). Dalam bahasa Indonesia, boboko disebut dengan bakul. Pengetahuan generasi milenial Sunda perkotaan terhadap boboko dapat dilihat dalam tabel 13 berikut.

Tabel 13

Pengetahuan Subjek Penelitian terhadap Boboko

\begin{tabular}{|c|c|c|c|}
\hline \multicolumn{3}{|c|}{ Wilayah * Boboko Crosstabulation } \\
\hline & \multicolumn{2}{|c|}{ Boboko } & \multirow{2}{*}{ Total } \\
\cline { 2 - 3 } & Tidak tahu & Tahu & \\
\hline $\begin{array}{c}\text { Count } \\
\% \text { within } \\
\text { Wilayah }\end{array}$ & 4 & 82 & 86 \\
\cline { 2 - 3 } & $4.7 \%$ & $95.3 \%$ & $100.0 \%$ \\
\hline
\end{tabular}

Berdasarkan tabel 13 terlihat bahwa 4 orang $(4,7 \%)$ responden generasi milenial di wilayah perkotaan juga tidak tahu alat dapur boboko dan 82 orang $(95,3 \%)$ responden di wilayah perkotaan mengetahui boboko. Berdasarkan uraian tadi dapat disimpulkan bahwa hampir seluruh generasi milenial Sunda di perkotaan tahu alat dapur boboko.

\section{Songsong}

Songsong adalah seruas bambu sebesar ibu jari yang berfungsi untuk meniup bara api di tungku agar api menyala kembali (Danadibrata, 2009). Pengetahuan generasi milenial Sunda perkotaan terhadap songsong dapat dilihat dalam tabel 14 berikut.

Tabel 14

Pengetahuan Subjek Penelitian terhadap Songsong

\begin{tabular}{|l|c|c|c|}
\hline \multicolumn{3}{|c|}{ Wilayah * Songsong Crosstabulation } \\
\hline \multirow{2}{*}{} & \multicolumn{2}{|c|}{ Songsong } & \multirow{2}{*}{} \\
\cline { 2 - 4 } & $\begin{array}{c}\text { Tidak } \\
\text { tahu }\end{array}$ & Tahu & Total \\
\hline $\begin{array}{l}\text { Count } \\
\text { \% within } \\
\text { Wilayah }\end{array}$ & 20 & 66 & 86 \\
\cline { 2 - 4 } & $23.3 \%$ & $76.7 \%$ & $100.0 \%$ \\
\hline
\end{tabular}

Berdasarkan tabel 14 terlihat bahwa 20 orang $(23,3 \%)$ responden generasi milenial di wilayah perkotaan tidak tahu songsong dan 66 orang $(76,7 \%)$ responden di wilayah perkotaan mengetahuinya. Berdasarkan uraian tadi dapat disimpulkan bahwa sebagian besar generasi milenial Sunda di perkotaan tahu alat dapur songsong.

\section{Ayakan}

Ayakan adalah alat yang terbuat dari anyaman bilah bambu halus berbentuk bulat, biasanya digunakan untuk memisahkan bahan curah dan bubuk yang memiliki ukuran kecil. Ayakan biasanya digunakan juga untuk menangkap benih ikan atau untuk penampungan ikan sementara. Pengetahuan generasi milenial Sunda perkotaan terhadap ayakan dapat dilihat dalam tabel 15 berikut.

Tabel 15

Pengetahuan Subjek Penelitian terhadap Ayakan

\begin{tabular}{|c|c|c|c|}
\hline \multicolumn{4}{|c|}{ Wilayah * Ayakan Crosstabulation } \\
\hline & \multicolumn{2}{|c|}{ Ayakan } & \multirow[b]{2}{*}{ Total } \\
\hline & Tidak tahu & Tahu & \\
\hline \multirow{2}{*}{$\begin{array}{l}\text { Count } \\
\% \text { within } \\
\text { Wilayah }\end{array}$} & 24 & 62 & 86 \\
\hline & $27.9 \%$ & $72.1 \%$ & $100.0 \%$ \\
\hline
\end{tabular}


Berdasarkan tabel 15 terlihat bahwa 24 orang $(27,9 \%)$ responden generasi milenial di wilayah perkotaan juga tidak tahu ayakan dan 62 orang $(72,1 \%)$ responden di wilayah perkotaan mengetahui ayakan. Berdasarkan uraian tadi dapat disimpulkan bahwa lebih dari setengah generasi milenial Sunda di perkotaan tahu alat dapur ayakan.

\section{Dulang-Halu}

Dulang biasanya terbuat dari kayu gelondongan dengan cara diberi lubang, ukurannya besar dan setengah cekung, berfungsi untuk mencampur nasi dalam proses ngarih dan ngakeul (Rosidi, dkk., 2000). Sementara itu, halu terbuat dari kayu yang berbentuk bulat panjang sebesar genggaman tangan, berfungsi untuk menumbuk padi atau beras. Pengetahuan generasi milenial Sunda perkotaan terhadap dulang-halu dapat dilihat dalam tabel 16 berikut.

Tabel 16

Pengetahuan Subjek Penelitian terhadap Dulang-Halu

\begin{tabular}{|l|c|c|c|}
\hline \multicolumn{3}{|c|}{ Wilayah * Dulang_halu Crosstabulation } \\
\hline \multirow{2}{*}{} & \multicolumn{2}{|c|}{ Dulang_halu } & \multirow{2}{*}{ Total } \\
\cline { 2 - 3 } & Tidak tahu & Tahu & 86 \\
\hline $\begin{array}{l}\text { Count } \\
\text { \% within } \\
\text { Wilayah }\end{array}$ & 22 & 64 & $100.0 \%$ \\
\cline { 2 - 3 } & $25.6 \%$ & $74.4 \%$ & \\
\hline
\end{tabular}

Berdasarkan tabel 16 terlihat bahwa sebanyak 22 orang $(25,6 \%)$ responden generasi milenial di wilayah perkotaan tidak tahu alat dapur dulang-halu dan 64 orang (74,4\%) mengetahui dulang-halu. Berdasarkan uraian tadi dapat disimpulkan bahwa lebih dari setengah generasi milenial Sunda di perkotaan tahu alat dapur dulang halu.

\section{Jojodog}

Jojodog adalah alat rumah tangga di dapur tradisional masyarakat Sunda. Jojodog adalah semacam bangku pendek dari kayu untuk duduk di depan tungku atau hawu. Pengetahuan generasi milenial Sunda perkotaan terhadap jojodog dapat dilihat dalam tabel 17 berikut.

Tabel 17

Pengetahuan Subjek Penelitian terhadap Jojodog

\begin{tabular}{|l|c|c|c|}
\hline \multicolumn{3}{|c|}{ Wilayah * Jojodog Crosstabulation } \\
\hline \multirow{2}{*}{} & \multicolumn{2}{|c|}{ Jojodog } & \multirow{2}{*}{ Total } \\
\cline { 2 - 3 } & Tidak tahu & Tahu & 86 \\
\hline $\begin{array}{l}\text { Count } \\
\text { \% within } \\
\text { Wilayah }\end{array}$ & 2 & 84 & $100.0 \%$ \\
\cline { 2 - 3 } & $2.3 \%$ & $97.7 \%$ & \\
\hline
\end{tabular}

Berdasarkan tabel 17 terlihat bahwa sebanyak 2 orang $(2,3 \%)$ responden generasi milenial di wilayah perkotaan tidak tahu alat dapur jojodog dan 84 orang $(97,7 \%)$ mengetahui jojodog. Berdasarkan uraian tadi dapat disimpulkan bahwa hampir seluruhnya generasi milenial Sunda di perkotaan tahu alat dapur jojodog.

\section{Tetenong}

Tetenong adalah alat rumah tangga di dapur masyarakat Sunda yang terbuat dari anyaman bambu yang dilengkapi dengan tutup yang kedap, berbentuk silinder berdiameter kurang lebih $60 \mathrm{~cm}$ s.d. $100 \mathrm{~cm}$, berfungsi sebagai wadah khusus makanan siap santap. Pengetahuan generasi milenial Sunda perkotaan terhadap tetenong dapat dilihat dalam tabel 18 berikut.

Tabel 18

Pengetahuan Subjek Penelitian terhadap Tetenong

\begin{tabular}{|c|c|c|c|}
\hline \multicolumn{4}{|c|}{ Wilayah * Tetenong Crosstabulation } \\
\hline & \multicolumn{2}{|c|}{ Tetenong } & Total \\
\hline & Tidak tahu & Tahu & \\
\hline \multirow{2}{*}{$\begin{array}{l}\text { Count } \\
\% \text { within } \\
\text { Wilayah }\end{array}$} & 24 & 62 & 86 \\
\hline & $27.9 \%$ & $72.1 \%$ & $100.0 \%$ \\
\hline
\end{tabular}

Berdasarkan tabel 18 terlihat bahwa sebanyak 24 orang $(27,9 \%)$ responden generasi milenial di wilayah perkotaan tidak tahu alat dapur tetenong dan 62 orang $(72,1 \%)$ mengetahui tetenong. Berdasarkan uraian tadi dapat disimpulkan bahwa sebagian besar generasi milenial Sunda di perkotaan tahu alat dapur tetenong. 


\section{Seeng}

Seeng adalah alat rumah tangga di dapur masyarakat Sunda berbahan dasar logam campuran antara tembaga dan kuningan berwarna merah kecoklatan. Bentuknya mirip panci besar yang ramping di bagian tengah. Seeng digunakan untuk memasak berbagai keperluan. Pada saat menanak nasi, seeng akan digabung dengan aseupan. Pengetahuan generasi milenial Sunda perkotaan terhadap seeng dapat dilihat dalam tabel 19 berikut.

\section{Tabel 19}

Pengetahuan Subjek Penelitian terhadap Seeng

\begin{tabular}{|c|c|c|c|}
\hline \multicolumn{3}{|c|}{ Wilayah * Seeng Crosstabulation } \\
\hline & \multicolumn{2}{|c|}{ Seeng } & \multirow{2}{*}{ Total } \\
\cline { 2 - 3 } & Tidak tahu & Tahu & \\
\hline $\begin{array}{c}\text { Count } \\
\% \text { within } \\
\text { Wilayah }\end{array}$ & 18 & 68 & 86 \\
\cline { 2 - 3 } & $20.9 \%$ & $79.1 \%$ & $100.0 \%$ \\
\hline
\end{tabular}

Berdasarkan tabel 19 terlihat bahwa sebanyak 18 orang $(20,9 \%)$ responden generasi milenial di wilayah perkotaan tidak tahu alat dapur seeng dan 68 orang $(79,1 \%)$ mengetahui seeng. Berdasarkan uraian tadi dapat disimpulkan bahwa sebagian besar generasi milenial Sunda di perkotaan tahu alat dapur seeng.

\section{Hawu}

Hawu merupakan tungku yang dibuat dengan cara cukup sederhana, di antaranya menggunakan adonan tanah liat atau tumpukan bata merah. Hawu yang terbuat dari gerabah dilapisi adonan tanah liat. Hawu dibuat sedemikian rupa sehingga api dari suluh 'kayu bakar' dapat keluar melalui satu atau dua lubang di bagian atas hawu tempat meletakkan panci (Amirin, 2011). Pengetahuan generasi milenial Sunda perkotaan terhadap hawu dapat dilihat dalam tabel 20 berikut.

Tabel 20

Pengetahuan Subjek Penelitian terhadap Hawu

\begin{tabular}{|c|c|c|c|}
\hline \multicolumn{3}{|c|}{ Wilayah * Hawu Crosstabulation } \\
\hline & \multicolumn{2}{|c|}{ Hawu } & \multirow{2}{*}{ Total } \\
\cline { 2 - 3 } & Tidak tahu & Tahu & \\
\hline Count & 74 & 12 & 86 \\
\hline
\end{tabular}

\begin{tabular}{|c|c|c|c|}
\hline $\begin{array}{c}\text { \% within } \\
\text { Wilayah }\end{array}$ & $86.0 \%$ & $14.0 \%$ & $100.0 \%$ \\
\hline
\end{tabular}

Berdasarkan tabel 20 terlihat bahwa sebanyak 74 orang $(86,0 \%)$ responden generasi milenial di wilayah perkotaan tidak tahu alat dapur hawu dan 12 orang $(14,0 \%)$ mengetahui hawu. Berdasarkan uraian tadi dapat disimpulkan bahwa sebagian besar generasi milenial Sunda di perkotaan tidak tahu alat dapur hawu.

\section{Gentong}

Gentong adalah alat rumah tangga di dapur masyarakat Sunda yang berbentuk seperti tempayan besar, biasanya terbuat dari tanah liat, berfungsi untuk menyimpan air (KBBI). Pengetahuan generasi milenial Sunda perkotaan terhadap gentong dapat dilihat dalam tabel 21 berikut.

Tabel 21

Pengetahuan Subjek Penelitian terhadap Gentong

\begin{tabular}{|c|c|c|c|}
\hline \multicolumn{4}{|c|}{ Wilayah * Gentong Crosstabulation } \\
\hline \multirow{2}{*}{} & \multicolumn{2}{|c|}{ Gentong } & \multirow{2}{*}{ Total } \\
\cline { 2 - 3 } & Tidak tahu & Tahu & \\
\hline $\begin{array}{c}\text { Count } \\
\% \text { within } \\
\text { Wilayah }\end{array}$ & 1 & 85 & 86 \\
\cline { 2 - 3 } & $1.2 \%$ & $98.8 \%$ & $100.0 \%$ \\
\hline
\end{tabular}

Berdasarkan tabel 21 terlihat bahwa hanya 1 orang $(1,2 \%)$ responden generasi milenial di wilayah perkotaan tidak tahu alat dapur gentong dan 85 orang $(98,8 \%)$ mengetahui gentong.

\section{Coet-Mutu}

Coet-mutu adalah sepasang alat rumah tangga di dapur masyarakat Sunda yang terbuat dari bahan yang keras, seperti kayu keras, batu, keramik, atau logam. Coet-mutu berfungsi untuk mengulek dan melumat bahan-bahan tertentu, misalnya bumbu dapur, rempah-rempah, jamu, atau obatobatan. Pengetahuan generasi milenial Sunda perkotaan terhadap coet-mutu dapat dilihat dalam tabel 22 berikut. 
Tabel 22

Pengetahuan Subjek Penelitian terhadap Coet-Mutu

\begin{tabular}{|l|c|c|}
\hline \multicolumn{2}{|c|}{ Wilayah * Coet-Mutu Crosstabulation } \\
\hline \multirow{2}{*}{$\begin{array}{l}\text { Count } \\
\text { \% within Wilayah }\end{array}$} & Tahu & \multirow{2}{*}{ Total } \\
\cline { 2 - 2 } & 86 & 86 \\
\hline
\end{tabular}

Berdasarkan tabel 22 terlihat bahwa semua responden generasi milenial di wilayah perkotaan sebanyak 86 orang $(100 \%)$ mengetahui alat dapur coet-mutu.

\section{Parud}

Parud adalah alat rumah tangga di dapur masyarakat Sunda untuk mengukur kelapa, keju, wortel, dan sebagainya, dibuat dari papan, logam, dan sebagainya, berpaku kawat banyak (KBBI). Pengetahuan generasi milenial Sunda perkotaan terhadap parud dapat dilihat dalam tabel 23 berikut.

Tabel 23

Pengetahuan Subjek Penelitian terhadap Parud

\begin{tabular}{|l|c|c|c|}
\hline \multicolumn{3}{|c|}{ Wilayah * Parud Crosstabulation } \\
\hline \multirow{2}{*}{} & \multicolumn{2}{|c|}{ Parud } & \multirow{2}{*}{ Total } \\
\cline { 2 - 3 } & Tidak tahu & Tahu & 86 \\
\hline $\begin{array}{l}\text { Count } \\
\text { \% within } \\
\text { Wilayah }\end{array}$ & 1 & 85 & $100.0 \%$ \\
\cline { 2 - 3 } & $1.2 \%$ & $98.8 \%$ & \\
\hline
\end{tabular}

Berdasarkan tabel 23 terlihat bahwa hanya 1 orang $(1,2 \%)$ responden generasi milenial di wilayah perkotaan tidak tahu alat dapur parud dan 85 orang $(98,8 \%)$ mengetahui parud.

\section{Kastrol}

Kastrol parabot tina beusi piranti ngaliwet 'kastrol perabot dari besi untuk ngaliwet' (Danadibrata, 2006). Dalam bahasa Indonesia alat ini didefinisikan sebagai periuk, alat untuk menanak nasi, dibuat dari tanah atau logam (KBBI). Pengetahuan generasi milenial Sunda perkotaan terhadap kastrol dapat dilihat dalam tabel 24 berikut.
Tabel 24

Pengetahuan Subjek Penelitian terhadap Kastrol

\begin{tabular}{|c|c|c|c|}
\hline \multicolumn{3}{|c|}{ Wilayah * Kastrol Crosstabulation } \\
\hline & \multicolumn{2}{|c|}{ Kastrol } & \multirow{2}{*}{ Total } \\
\cline { 2 - 3 } & Tidak tahu & Tahu & \\
\hline $\begin{array}{c}\text { Count } \\
\text { \% within } \\
\text { Wilayah }\end{array}$ & 14 & 72 & 86 \\
\cline { 2 - 3 } & $16.3 \%$ & $83.7 \%$ & $100.0 \%$ \\
\hline
\end{tabular}

Berdasarkan tabel 24 terlihat bahwa sebanyak 14 orang $(16,3 \%)$ responden generasi milenial di wilayah perkotaan tidak tahu alat dapur kastrol dan 72 orang $(83,7 \%)$ mengetahui kastrol. Berdasarkan uraian tadi dapat disimpulkan bahwa sebagian besar generasi milenial Sunda di perkotaan tahu alat dapur kastrol.

\section{Panci}

Panci adalah alat rumah tangga di dapur masyarakat Sunda, terbuat dari logam (aluminium, baja, dan sebagainya), bertelinga pada kedua sisinya, berbentuk silinder atau mengecil pada bagian bawahnya, biasanya digunakan memasak air, sayur berkuah, dan sebagainya (KBBI). Pengetahuan generasi milenial Sunda perkotaan terhadap panci dapat dilihat dalam tabel 25 berikut.

Tabel 25

Pengetahuan Subjek Penelitian terhadap Panci

\begin{tabular}{|c|c|c|c|}
\hline \multicolumn{4}{|c|}{ Wilayah * Panci Crosstabulation } \\
\hline & \multicolumn{2}{|c|}{ Panci } & \multirow{2}{*}{ Total } \\
\hline & Tidak tahu & Tahu & \\
\hline \multirow{2}{*}{$\begin{array}{c}\text { Count } \\
\% \text { within } \\
\text { Wilayah }\end{array}$} & 4 & 82 & 86 \\
\hline & $4.7 \%$ & $95.3 \%$ & $100.0 \%$ \\
\hline
\end{tabular}

Berdasarkan tabel 25 terlihat bahwa hanya 4 orang $(4,7 \%)$ responden generasi milenial di wilayah perkotaan tidak tahu alat dapur panci dan 82 orang $(95,3 \%)$ mengetahui pancil. Berdasarkan uraian tadi dapat disimpulkan bahwa hampir seluruh generasi milenial Sunda di perkotaan tahu alat dapur panci. 
Teko

Teko adalah alat rumah tangga di dapur masyarakat Sunda, biasanya terbuat dari seng atau tembaga, sebagai tempat air minum. Pengetahuan generasi milenial Sunda perkotaan terhadap teko dapat dilihat dalam tabel 26 berikut.

Tabel 26

Pengetahuan Subjek Penelitian terhadap Teko

\begin{tabular}{|c|c|c|c|}
\hline \multicolumn{3}{|c|}{ Wilayah * Teko Crosstabulation } \\
\hline & \multicolumn{2}{|c|}{ Teko } & \multirow{2}{*}{ Total } \\
\cline { 2 - 3 } & Tidak tahu & Tahu & \\
\hline $\begin{array}{c}\text { Count } \\
\text { \% within } \\
\text { Wilayah }\end{array}$ & 2 & 84 & 86 \\
\cline { 2 - 3 } & $2.3 \%$ & $97.7 \%$ & $100.0 \%$ \\
\hline
\end{tabular}

Berdasarkan tabel 26 terlihat bahwa hanya 2 orang $(2,3 \%)$ responden generasi milenial di wilayah perkotaan tidak tahu alat dapur teko dan 84 orang $(97,7 \%)$ mengetahui teko.

\section{Rantang}

Rantang adalah panci bersusun dan bertutup untuk tempat makanan dengan dilengkapi tangkai yang berfungsi sebagai pengait dan pegangan (KBBI). Pengetahuan generasi milenial Sunda perkotaan terhadap rantang dapat dilihat dalam tabel 27 berikut.

Tabel 27

Pengetahuan Subjek Penelitian terhadap Rantang

\begin{tabular}{|c|c|c|c|}
\hline \multicolumn{4}{|c|}{ Wilayah * Rantang Crosstabulation } \\
\hline & \multicolumn{2}{|c|}{ Rantang } & \multirow{2}{*}{ Total } \\
\cline { 2 - 3 } & Tidak tahu & Tahu & \\
\hline $\begin{array}{c}\text { Count } \\
\% \text { within } \\
\text { Wilayah }\end{array}$ & 0 & 86 & 86 \\
\cline { 2 - 3 } & $0.0 \%$ & $100.0 \%$ & $100.0 \%$ \\
\hline
\end{tabular}

Berdasarkan tabel 27 terlihat bahwa semua responden (100\%) mengetahui rantang.

Peso

Peso adalah alat rumah tangga di dapur masyarakat Sunda yang terbuat dari logam atau besi yang dilapisi baja dengan gagang biasanya dari kayu, berfungsi sebagai alat pemotong dan pengiris. Pengetahuan generasi milenial Sunda perkotaan terhadap peso dapat dilihat dalam tabel 28 berikut.
Tabel 28

Pengetahuan Subjek Penelitian terhadap Peso

\begin{tabular}{|c|c|c|c|}
\hline \multicolumn{3}{|c|}{ Wilayah * Peso Crosstabulation } \\
\hline & \multicolumn{2}{|c|}{ Peso } & \multirow{2}{*}{ Total } \\
\cline { 2 - 3 } & Tidak tahu & Tahu & \\
\hline $\begin{array}{c}\text { Count } \\
\% \text { within } \\
\text { Wilayah }\end{array}$ & 1 & 85 & 86 \\
\cline { 2 - 3 } & $1.2 \%$ & $98.8 \%$ & $100.0 \%$ \\
\hline
\end{tabular}

Berdasarkan tabel 28 terlihat bahwa hanya 1 orang $(1,2 \%)$ responden generasi milenial di wilayah perkotaan yang tidak tahu alat dapur peso dan 85 orang $(98,8 \%)$ mengetahui peso.

Mangkok

Mangkok dalam bahasa Indonesia disebut mangkuk. Mangkuk adalah tempat untuk makanan yang berkuah, tidak bertelinga, cekung, bundar, bagian permukaannya lebih luas daripada bagian alasnya, terbuat dari porselen atau bahan lain (KBBI). Pengetahuan generasi milenial Sunda perkotaan terhadap mangkok dapat dilihat dalam tabel 29 berikut.

Tabel 29

Pengetahuan Subjek Penelitian terhadap Mangkok

\begin{tabular}{|c|c|c|c|}
\hline \multicolumn{4}{|c|}{ Wilayah * Mangkok Crosstabulation } \\
\hline & \multicolumn{2}{|c|}{ Mangkok } & \multirow{2}{*}{ Total } \\
\cline { 2 - 3 } & Tidak tahu & Tahu & \\
\hline $\begin{array}{c}\text { Count } \\
\% \text { within } \\
\text { Wilayah }\end{array}$ & 2 & 84 & 86 \\
\cline { 2 - 3 } & $2.3 \%$ & $97.7 \%$ & $100.0 \%$ \\
\hline
\end{tabular}

Berdasarkan tabel 29 terlihat bahwa hanya 2 orang $(2,3 \%)$ responden generasi milenial di wilayah perkotaan tidak tahu alat dapur mangkok dan 84 orang $(97,7 \%)$ mengetahui mangkok. Berdasarkan uraian tadi dapat disimpulkan bahwa hampir seluruh generasi milenial Sunda di perkotaan tahu alat dapur mangkok.

\section{Termos}

Termos dalam bahasa Indonesia pun disebut termos. Termos adalah botol yang diberi dinding rangkap untuk menyimpan minuman agar tetap memiliki suhu yang semula (KBBI). Pengetahuan generasi 
milenial Sunda perkotaan terhadap termos dapat dilihat dalam tabel 30 berikut.

Tabel 30

Pengetahuan Subjek Penelitian terhadap Termos

\begin{tabular}{|l|c|c|c|}
\hline \multicolumn{3}{|c|}{ Wilayah * Termos Crosstabulation } \\
\hline \multirow{2}{*}{} & \multicolumn{2}{|c|}{ Termos } & \multirow{2}{*}{ Total } \\
\cline { 2 - 3 } & Tidak tahu & Tahu & Tol \\
\hline $\begin{array}{l}\text { Count } \\
\text { \% within } \\
\text { Wilayah }\end{array}$ & 3 & 83 & 86 \\
\cline { 2 - 3 } & $3.5 \%$ & $96.5 \%$ & $100.0 \%$ \\
\hline
\end{tabular}

Berdasarkan tabel 30 terlihat bahwa hanya 3 orang $(3,5 \%)$ responden generasi milenial di wilayah perkotaan tidak tahu alat dapur termos dan 83 orang $(96,5 \%)$ mengetahui termos.

\section{Baskom}

Baskom disebut juga baskom dalam bahasa Indonesia. Baskom adalah tempat air pencuci tangan atau muka (KBBI). Pengetahuan generasi milenial Sunda perdesaan dan perkotaan terhadap baskom dapat dilihat dalam tabel 31 berikut.

Tabel 31

Pengetahuan Subjek Penelitian terhadap Baskom

\begin{tabular}{|c|c|c|c|}
\hline \multicolumn{3}{|c|}{ Wilayah * Baskom Crosstabulation } \\
\hline & \multicolumn{2}{|c|}{ Baskom } & \multirow{2}{*}{ Total } \\
\cline { 2 - 3 } & Tidak tahu & Tahu & \\
\hline $\begin{array}{c}\text { Count } \\
\text { \% within } \\
\text { Wilayah }\end{array}$ & 6 & 80 & 86 \\
\cline { 2 - 3 } & $7.0 \%$ & $93.0 \%$ & $100.0 \%$ \\
\hline
\end{tabular}

Berdasarkan tabel 31 terlihat bahwa sebanyak 6 orang $(7,0 \%)$ responden generasi milenial di wilayah perkotaan tidak tahu alat dapur baskom dan 80 orang $(93,0 \%)$ mengetahui baskom.

\section{Sinduk}

Sinduk adalah sendok besar yang terbuat dari batok. Sinduk ada pula yang terbuat dari kaleng, seng, aluminium, atau plastik. Kegunaannya adalah untuk menyendok sayur dari katél, lalayah, dan sebagainya (Danadibrata, 2009:640). Pengetahuan generasi milenial Sunda perkotaan terhadap siduk dapat dilihat dalam tabel 32 berikut.
Tabel 32

Pengetahuan Subjek Penelitian terhadap Sinduk

\begin{tabular}{|c|c|c|c|}
\hline \multicolumn{4}{|c|}{ Wilayah * Sinduk Crosstabulation } \\
\hline & \multicolumn{2}{|c|}{ Sinduk } & \multirow{2}{*}{ Total } \\
\hline & Tidak tahu & Tahu & \\
\hline \multirow{2}{*}{$\begin{array}{l}\text { Count } \\
\% \text { within } \\
\text { Wilayah }\end{array}$} & 7 & 79 & 86 \\
\hline & $8.1 \%$ & $91.9 \%$ & $100.0 \%$ \\
\hline
\end{tabular}

Berdasarkan tabel 32 terlihat bahwa sebanyak 7 orang $(8,1 \%)$ responden generasi milenial di wilayah perkotaan tidak tahu alat dapur sinduk dan 79 orang $(91,9 \%)$ mengetahui sinduk.

\section{Serok}

Serok merupakan alat masak yang digunakan untuk menyauk atau meraup benda-benda yang di dalam minyak ketika menggoreng. Serok berfungsi untuk meniriskan minyak dari makanan yang digoreng. Pengetahuan generasi milenial Sunda perkotaan terhadap serok dapat dilihat dalam tabel 33 berikut.

Tabel 33

Pengetahuan Subjek Penelitian terhadap Serok

\begin{tabular}{|c|c|c|c|}
\hline \multicolumn{3}{|c|}{ Wilayah * Serok Crosstabulation } \\
\hline & \multicolumn{2}{|c|}{ Serok } & \multirow{2}{*}{ Total } \\
\cline { 2 - 3 } & Tidak tahu & Tahu & \\
\hline $\begin{array}{c}\text { Count } \\
\% \text { within } \\
\text { Wilayah }\end{array}$ & 7 & 79 & 86 \\
\cline { 2 - 3 } & $8.1 \%$ & $91.9 \%$ & $100.0 \%$ \\
\hline
\end{tabular}

Berdasarkan tabel 33 terlihat bahwa sebanyak 7 orang $(8,1 \%)$ responden generasi milenial di wilayah perkotaan tidak tahu alat dapur serok dan 79 orang $(91,9 \%)$ mengetahui serok.

\section{Baki}

Baki dalam KBBI disebut juga talam atau nampan, yakni tempat untuk menyajikan makanan dan minuman terbuat dari kayu, logam, dan sebagainya, ada yang berkaki dan ada yang bertelinga. Pengetahuan generasi milenial Sunda perkotaan terhadap baki dapat dilihat dalam tabel 34 berikut. 
Tabel 34

Pengetahuan Subjek Penelitian terhadap Baki

\begin{tabular}{|c|c|c|c|}
\hline \multicolumn{3}{|c|}{ Wilayah * Baki Crosstabulation } \\
\hline & \multicolumn{2}{|c|}{ Baki } & \multirow{2}{*}{ Total } \\
\cline { 2 - 3 } & Tidak tahu & Tahu & \\
\hline $\begin{array}{c}\text { Count } \\
\% \text { within } \\
\text { Wilayah }\end{array}$ & 16 & 70 & 86 \\
\cline { 2 - 3 } & $18.6 \%$ & $81.4 \%$ & $100.0 \%$ \\
\hline
\end{tabular}

Berdasarkan tabel 34 terlihat bahwa sebanyak 16 orang $(18,6 \%)$ responden generasi milenial di wilayah perkotaan tidak tahu alat dapur baki dan 70 orang $(81,40 \%)$ mengetahui baki.

\section{Susuk}

Susuk adalah alat untuk membolak-balik makanan yang sedang digoreng (Sumantri, dkk., 1985). Pengetahuan generasi milenial Sunda perkotaan terhadap susuk dapat dilihat dalam tabel 35 berikut.

Tabel 35

Pengetahuan Subjek Penelitian terhadap Susuk

\begin{tabular}{|c|c|c|c|}
\hline \multicolumn{3}{|c|}{ Wilayah * Susuk Crosstabulation } \\
\hline & \multicolumn{2}{|c|}{ Susuk } & \multirow{2}{*}{ Total } \\
\cline { 2 - 3 } & Tidak tahu & Tahu & \\
\hline $\begin{array}{c}\text { Count } \\
\text { \% within } \\
\text { Wilayah }\end{array}$ & 9 & 77 & 86 \\
\cline { 2 - 3 } & $10.5 \%$ & $89.5 \%$ & $100.0 \%$ \\
\hline
\end{tabular}

Berdasarkan tabel 35 terlihat bahwa sebanyak 9 orang $(10,5 \%)$ responden generasi milenial di wilayah perkotaan tidak tahu alat dapur susuk dan 77 orang $(89,5 \%)$ mengetahui susuk.

\section{Hasil Pengolahan Data Pengetahuan Generasi Milenial Sunda Perkotaan terhadap Peralatan di Dapur Tradisional Sunda}

Analisis data untuk menjawab rumusan masalah dilakukan secara statistika deskriptif dengan langkah sebagai berikut.

1) Menghitung skor total jawaban setiap subjek penelitian.

2) Mengubah skor total pengetahuan setiap subjek penelitian dalam bentuk persentase sehingga akan diperoleh rentang skor dari 0 sampai dengan 100 .

3) Menghitung rata-rata skor total pengetahuan dari seluruh subjek penelitian.

4) Mengategorikan nilai rata-rata skor total hasil langkah (3) berdasarkan interval dan predikat KKM dari Tim Direktorat Pembinaan Pendidikan Dasar Pertama (2017) seperti dalam tabel 36 berikut.

Tabel 36

Kategori Pengetahuan Subjek Penelitan

\begin{tabular}{|c|l|}
\hline Interval Pengetahuan & \multicolumn{1}{|c|}{ Kategori } \\
\hline $88 \leq$ Pengetahuan $\leq 100$ & Sangat Baik \\
\hline $74 \leq$ Pengetahuan $<88$ & Baik \\
\hline $60 \leq$ Pengetahuan $<74$ & Cukup \\
\hline Pengetahuan $<60$ & Kurang \\
\hline
\end{tabular}

Sumber: Tim Direktorat Pembinaan SMP (2017).

Interpretasi hasil pengolahan data pengetahuan subjek penelitian tentang kosakata peralatan rumah tangga di dapur tradisional Sunda mengacu pada tabel 37 berikut.

Tabel 37

Statistik Pengetahuan Subjek Penelitian terhadap Alat Rumah Tangga

\begin{tabular}{|c|c|c|c|c|}
\hline \multicolumn{4}{|c|}{ Group Statistics } \\
\hline Wilayah & $\mathrm{N}$ & Mean & Std. Deviation & Std. Error Mean \\
\hline $\begin{array}{c}\text { Pengetahuan alat rumah tangga generasi } \\
\text { milenial perkotaan }\end{array}$ & 86 & 87.1705 & 11.93137 & 1.28659 \\
\hline
\end{tabular}


Berdasarkan tabel 37 diketahui bahwa pengetahuan generasi milenial Sunda perkotaaan terhadap kosakata peralatan rumah tangga di dapur tradisional Sunda sudah mencapai rata-rata $87,17 \%$ sehingga dapat dikategorikan baik (Tim Direktorat Pembinaan SMP, 2017).

\section{PENUTUP}

Dari analisis dan pembahasan dapat disimpulkan bahwa pengetahuan generasi milenial Sunda perkotaaan terhadap kosakata peralatan rumah tangga di dapur tradisional Sunda sudah mencapai ratarata $87,17 \%$ sehingga dapat dikategorikan baik. Terdapat sekelompok generasi milenial Sunda di perkotaan yang mengetahui keseluruhan peralatan rumah tangga di dapur tradisional Sunda yang ditanyakan, tetapi ada juga kelompok generasi melineal lainnya yang hanya mengetahui setengahnya.

Beberapa alat rumah tangga di dapur tradisional Sunda yang saat ini sudah jarang digunakan, seperti hihid, masih diketahui oleh semua responden generasi milenial Sunda di perkotaan. Selain itu, jojodog dan gentong ternyata masih diketahui oleh hampir seluruh responden generasi milenial di perkotaan. Aseupan, songsong, seeng, nyiru, tolombong, tetenong, dan kastrol ternyata masih diketahui oleh sebagian besar generasi milenial di perkotaan. Begitu juga dengan alat dulang-halu lebih dari setengah responden generasi milenial di perkotaan masih mengetahuinya.

Sebagian besar responden generasi milenial di perkotaan tidak mengenal hawu. Tungku tempat memasak tersebut memang saat ini sulit sekali ditemukan di wilayah perkotaan. Selain karena sulitnya mendapat kayu bakar, masyarakat perkotaan juga sudah menggantinya dengan kompor yang lebih praktis.

Secara keseluruhan, sikap positif generasi milenial Sunda terhadap peralatan dan istilah di dapur tradisional Sunda dalam penelitian ini sudah baik, tetapi belum tecermin dalam praktik sehari-hari. Perlu diadakan gerakan kesadaran mencintai bahasa Sunda kepada para orang tua agar mereka dapat mengenalkan bahasa Sunda kepada anakanaknya.

Berdasarkan hasil perhitungan, hanya terdapat empat orang responden (4.65\%) yang mengetahui semua alat tradisional yang ada di dapur Sunda yang ditanyakan. Berdasarkan hal tersebut, pengembangan sikap positif adalah suatu langkah dan upaya dalam pembinaan dan pengembangan sikap dan rasa bangga dalam memiliki dan menggunakan bahasa Sunda.

Perlu penelitian selanjutnya untuk melihat faktor yang menyebabkan sebagian generasi milenial Sunda tidak mengetahui kosakata dan istilah di dapur tradisional Sunda. Penelitian lain juga perlu dilakukan sebagai pembanding hasil yang diperoleh dari peneliitan ini.

\section{DAFTAR PUSTAKA}

Amirin, T. M. (2011). Sunda (dan Indonesia) Baheula. dalam https://tatangmanguny.wordpress.c om/kasundaan, diakses pada 12 Oktober 2020.

Badan Pengembangan dan Pembinaan Bahasa. (n.d.). KBBI daring dalam https://kbbi.kemdikbud.go.id.

Bahasa, B. P. dan P. (n.d.). Bahasa di Provinsi Jawa Barat. "Bahasa dan Peta Bahasa di Indonesia", dalam https://petabahasa.kemdikbud.go.i d/provinsi.php?idp=Jawa\%20Barat diakses pada 21 November 2020

Bencsik, A., Csikos, G., \& Juhaz, T. (2016). Y and Z Generations at Workplaces. Journal of Competitiveness, $90-106$. https://doi.org/10.7441/joc.2016.03 .06 
Chaer, A. dan A. (2010). Sosiolinguistik: Perkenalan Awal. Jakarta: Rineka Cipta.

Danadibrata, R. . (2006). Kamus Basa Sunda. Bandung: Kiblat Buku Utama.

Danadibrata, R. . (2009). Kamus Basa Sunda. Bandung: Kiblat Buku Utama.

David, C. (1990). Language Death. Cambridge: Cambridge University Press.

Direktorat Pembinaan Pendidikan Dasar Pertama. (2017). Panduan Penilaian Untuk Sekolah Menengah. Ditjen Dikdasmen Kemendikbud.

Febriani, N. S. (2020). Preferensi Media Sosial Generasi Milenial pada Tingkat Pengetahuan Calon Legislatif. NYIMAK: Journal Comunication, 4. https://doi.org/10.31000/nyimak.v $4 \mathrm{i} 1.2225$

Halim, A. (1983). Sikap Bahasa dan Pelaksanaan Kebijaksanaan Bahasa Nasional. Depdikbud.

Hudson, R. A. (1996). Sociolinguistics. Cambridge: Cambridge University Press. https://doi.org/10.1017/CBO97811 39166843

Lauder. (2012). "The Role of Media and ICT in Safeguarding and Promoting Language Diversity in Asia and Europe."

Lewis. M. Paul Gary. F. Simons and Charles D. Fenning (ed). (2013). Ethnology Language of the World (Seventeent). SIL International.

Mahsun. (2005). Metode Penelitian Bahasa: Tahapan Strategi, Metode, dan Tekniknya. Jakarta: Raja Grafindo Persada.

Markus, D. (2017). Penguasaan Kosakata Bahasa Indonesia Anak Usia 4-5 Tahun. FENOMENA: Jurnal Ilmiah, 4. https://doi.org/10.25139/fonema.v $4 \mathrm{i} 2.762$

Multamia, L. (2004). Optimalisasi Bahasa Indonesia Berbasis Korpus Linguistik.

Rosidi, A. dkk. (2000). Ensiklopedi Sunda: Alam, Manusia, Budaya. Jakarta: Pustaka Jaya.

SIL Internasional. (2001). Languages of Indonesia. SIL International, Indonesia Branch.

Sobarna. (2007). Bahasa Sunda sudah di Pintu Kematiankah? Makara: Sosial Humaniora, 11. https://doi.org/10.7454/mssh.v11i1 .39

Sucipto, T. (2000). Kebudayaan Masyarakat Sunda di Kabupaten Lebak. Direktorat Sejarah dan Nilai Tradisional, Proyek P2NB Jawa Barat.

Sumantri, dkk. (1985). Kamus SundaIndonesia. Pusat Pembinaan dan Pengembangan Bahasa Departemen Pendidikan dan Kebudayaan.

Sumarsono. (1993). Pemertahanan Bahasa Melayu Loloan di Bali. Pusat Pembinaan dan Pengembangan Bahasa.

Sumarsono dan Partana, P. (2004). Sosiolinguistik. Yogyakarta: Sabda.

Suranny, L. E. (2015). Peralatan Dapur Tradisional sebagai Warisan Kekayaan Budaya Bangsa Indonesia. Jurnal Arkeologi Papua, 7. https://doi.org/10.24832/papua.v7i 1.37 